\title{
The Responses of Mathematics Pre-Service Teachers Toward Online Lectures in the Covid-19 Era
}

\author{
Imaludin Agus ${ }^{1,}$ a), Amanda La Hadi ${ }^{1}$ \\ ${ }^{1}$ Institut Agama Islam Negeri Kendari \\ 17 Sultan Qaimuddin Street, Baruga, Kota Kendari, Sulawesi Tenggara, Indonesia, 93563 \\ a)imaludinagus@iainkendari.ac.id
}

\begin{abstract}
Covid-19 pandemic had affected in paradigm changing of learning from face-to-face to online learning. It was not easily adapted by educators or students. This study aims to assessed responses from mathematics pre-service teachers about online lectures during the covid 19 outbreak. The research was a descriptive survey design that was conducted on 75 selected semester II-VI of math students in IAIN Kendari. Responses were obtained by questionnaires and interviews that further were collected, sorted, and categorized base on an online lecture platform. Our finding reveals that WhatsApp becomes the most entry and frequently platform that used in lectures (65.3\%), followed by Google Classroom (18.7\%), YouTube (2.7\%), e-mail (2.7\%), Facebook $(1.3 \%)$, and a combination of several media (9.3\%), while Zoom in the least preferred. The obstacles faced by students during online learning were poor internet connection, internet quota requirements, and limited online lecturing equipment. However, the possibility to study anywhere (home, garden, beach, etc.) and flexible learning time is the ease gained by the students in these methods. Meanwhile, in terms of effectiveness, we found some different responses including very effective $(1.3 \%)$, effective $(12 \%)$, less effective $(78.7 \%)$, ineffective $(2.7 \%)$, and very ineffective $(5.3 \%)$. Generally, most mathematics students $(60 \%)$ responded they want to meet face to face, and only $2.7 \%$ of them want online learning, and $(37.3 \%)$ want blended learning. Based on these results, blended learning could be a choice in the lecture by more attractive online media.
\end{abstract}

Keywords: Covid-19, Mathematics Pre-Service Teachers, Online Lecture.

\begin{abstract}
Abstrak. Pandemi covid-19 berdampak pada perubahan paradigma belajar dari tatap muka menjadi pembelajaran online. Hal ini tidak mudah diadaptasi oleh pendidik maupun peserta didik. Oleh karena itu, penelitian ini bertujuan untuk memperoleh tanggapan calon guru matematika tentang perkuliahan online di era pandemi covid19. Penelitian ini merupakan penelitian survey deskriptif dengan sampel dipilih secara purposive sebanyak 75 mahasiswa tadris matematika IAIN Kendari semester II-VI. Data diperoleh dengan menggunakan angket dan wawancara. Analisis data dilakukan dengan cara mengumpulkan, mengurutkan, dan mengkategorisasi. Berdasarkan data tersebut diperoleh bahwa platform online yang sering digunakan dalam perkuliahan diera covid-19 adalah WhatsApp (65,3\%), google clasroom $(18,7 \%)$, YouTube $(2,7 \%)$, e-mail $(2,7 \%)$, facebook $(1,3 \%)$, dan kombinasi beberapa media $(9,3 \%)$, dengan WhatsApp sebagai media online yang paling disukai dan Zoom yang tidak disukai. Hambatan yang dihadapi mahasiswa selama pembelajaran online yaitu jaringan internet yang terbatas, membutuhkan quota internet yang banyak, dan perangkat perkuliahan online yang minim, sedangkan kemudahan yang diperoleh yaitu dapat belajar dimana saja (rumah, kebun, pantai, dll) serta waktu belajar yang tidak terbatas. Keefektifan perkuliahan online yaitu sangat efektif (1,3\%), efektif (12\%), kurang efektif $(78,7 \%)$, tidak efektif $(2,7 \%)$ dan sangat tidak efektif $(5,3 \%)$. Secara umum, mahasiswa tadris matematika memberikan tanggapan bahwa ketika pandemi covid-19 berakhir $(60 \%)$ mahasiswa menginginkan tatap muka, $(2,7 \%)$ menginginkan online, dan $(37,3 \%)$ mengingikan blended learning. Berdasarkan hasil tersebut maka blended learning bisa menjadi alternatif pilihan dalam proses perkuliahan dengan mempergunakan media online yang lebih menarik.
\end{abstract}

Kata kunci: Covid-19, Mahasiswa Calon Guru Matematika, Perkuliahan Online. 


\section{INTRODUCTION}

The Coronavirus Disease (Covid-19) pandemic has hit most countries worldwide, as was Indonesia. Since early March 2020, the President of the Republic of Indonesia had declared the Covid-19 pandemic an extraordinary disaster. Along with this declaration, various policies were issued to break the chain of spreading of the virus including social distancing, working from home, and Large Scale Social Restrictions (PSBB). It's had an impact on all sectors of life, including education.

In the education sector, the policies were marked by the issuance of regulation of the Minister of Education and Culture Number 4, 2020 about the Implementation of Education Policies in the Emergency of the Spread of Covid-19 among of them including the cancellation of the National Examination (UN) for all levels of education and changes in learning patterns, from classically learning (face to face) becomes online learning. Particularly in State Islamic University (PTKIN), it had also impact on the implementation of online lectures based on the regulation of the Minister of Religion Affairs Number 697/03/2020 which was followed up by the State Islamic Institute of Kendari (IAIN Kendari) through the Circular of the Chancellor of IAIN Kendari Number 0125/ln.23/03/2020 concerning Online Lectures for all study programs.

The implementation of online lectures was a solution provided by the government to reduce the local transmission of covid-19 and ensuring that the lecture process continues as expected. It was in line with research conducted by Jolanta \& Majella (2020) which states that learning in educational institutions (schools and campuses) was closed during the Covid-19 pandemic by maintaining communication with students, parents, educators, and staff. Furthermore, Burke said that utilizing the online platform could be conducted to maintain communication with each academic community. In the same demonstration, Roy (2020) suggested the use of teleconferencing as an alternative to learning/lecturing in the Covid-19 era.

Online learning was defined as learning that utilizes information and communication technology (ICT) through internet media such as the Web, E-Learning, WhatsApp, Facebook, Zoom, Moodle, Google Classroom, Meet, YouTube, etc (Mulenga \& Marbán, 2020). Through the paradigm, the interaction between teachers and students was being virtual. Kurt (2010) demonstrated that using technology in learning able to improving thinking skills. Also, technologybased learning could increase the learning attractiveness of students (Viajayani, Radiyono, \& Rahardjo, 2013).

Specifically in mathematics learning, Setyaningrum (2018) stated that using online learning media (moodle) was effective in improving students' understanding of mathematical concepts. In addition, Perienen (2020) said that learning mathematics could be effective if used suitable 
technology. In relation, Mulenga \& Marbán (2020) stated in their research that digital learning in mathematics allows students to learn at home comfortably.

The success of online learning should be supported by adequate tools and the ability of individuals to manage the devices. However, the Covid-19 pandemic had obliged all educational institutions to conduct online learning with various existing digital platforms, led individual devices, and abilities in managing these digital devices are not optimal. As a result, the online learning process carried out during the Covid-19 pandemic had not been optimal. Anhusadar (2020) in their research that was carried out at the beginning of the implementation of online lectures, demonstrated that most students did not want to conduct online learning for various reasons, one of its was the absence of a supporting device. Besides, Mulenga \& Marbán (2020) states that mathematics learning in Zambia was not yet established in organizing online learning.

According to that fact, we conduct this study with the aims to determine the responses of mathematics pre-service teachers about online lectures in the Covid-19 pandemic. This research was important to assessed student responses during the lecture process, as well as to revealed their obstacles and strengths.

\section{METHOD}

In this research, we used a descriptive survey method, to 75 Semester II-VI students of Mathematics at IAIN Kendarithat selected by purposive based on the representation of each generation. The instruments were given were questionnaires and interviews. Questionnaires were given to respondents via a google form, while the interviewing respondents were taken as the representative manner by the required deepening of the information. The analysis of the research results was carried out by collecting, sorting, grouping, and categorizing.

\section{RESULTS AND DISCUSSION}

This research was conducted on mathematics education students of IAIN Kendari who took online lectures due to covid-19. The application of online lectures at IAIN Kendari was based on the regulation of the Chancellor of IAIN Kendari Number 0125/ln.23/03/2020 concerning Online Lectures using digital platforms. Online lecture platforms/media that were often used were presented in Table 1 . 
EDUMATIKA: Jurnal Riset Pendidikan Matematika

Table 1. Online Learning Platform Used

\begin{tabular}{ccc}
\hline Online Platform & Frequency & Percentage \\
\hline WhatsApp & 49 & $65,3 \%$ \\
\hline Google Classroom & 14 & $18,7 \%$ \\
\hline YouTube & 2 & $2,7 \%$ \\
\hline Email & 2 & $2,7 \%$ \\
\hline Facebook & 1 & $1,3 \%$ \\
\hline Combination & 7 & $9,3 \%$ \\
\hline
\end{tabular}

Based on Table 1, we show that from 75 students of the mathematics education program of IAIN Kendari during the online lectures in a pandemic era mostly used WhatsApp group as many as 49 students or $65.3 \%$, followed by Google Classroom 14 student (18.7\%), YouTube and Email 2 (2.7\%) respectively, Facebook of 1 respondent (1.3\%), and the combination (WhatsApp, YouTube, Classroom, Zoom, etc.) 7 student about 9.3\%. From this data, we also obtained students' responses about like and dislike of the online platform that was used in online lectures, which were presented in Table 2.

Table 2. Liked/Disliked Online Learning Platform

\begin{tabular}{ccc}
\hline \multirow{2}{*}{ Online Platform } & \multicolumn{3}{c}{ Percentage } \\
\cline { 2 - 3 } & Like & Dislike \\
\hline WhatsApp & $65,3 \%$ & $9,3 \%$ \\
\hline Google Classroom & $17,3 \%$ & $13,3 \%$ \\
\hline YouTube & $10,7 \%$ & $25,3 \%$ \\
\hline Email & $0 \%$ & $8 \%$ \\
\hline Facebook & $1,3 \%$ & $8 \%$ \\
\hline Zoom & $0 \%$ & $30,7 \%$ \\
\hline Others & $5,3 \%$ & $9,3 \%$ \\
\hline
\end{tabular}

Based on table 2, we found that WhatsApp was the most preferred media by students, namely as many as 49 students or $65.3 \%$ followed by Classroom and YouTube with 13 respondent like (17.3\%) and 8 (10.7\%) respectively. Contrarily with Whatsapp, Zoom becomes the most dislike platform of respondents about 23 students (30.7\%). Based on the interview with respondent1, WhatsApp was the preferred platform during online lectures because most of the students already have WhatsApp and they said interactions that were members of the group could occur quickly. Another important, WhatsApp was mostly liked because the required quota was relatively lower. Meanwhile, respondent-2 who likes classrooms argued the platform enabled lecturers to uploaded lecture materials (Teaching Materials, PPT, and Teaching Videos) on the platform that makes it easier to understand lecture material. Furthermore, the existing material could be studied at another time. Contrarily with that, respondents-3 stated that the Zoom platform was not liked by them because Zoom needed a good internet connection and a largely required internet quota, which made it difficult to adopt. However, to minimize those obstacles, IAIN Kendari provided internet quota subsidies to students in collaboration with one of the providers. In addition, based on data from BPS for Southeast Sulawesi Province in 2019, the majority of areas in Southeast Sulawesi 
were not covered by good internet connections that led to online learning still have an obstacle to conducted.

In the implementation of online lectures in the era of the Covid-19 pandemic, there were obstacles and advantages. The obstacles experienced by mathematics education program students at IAIN Kendari were presented in Table 3.

Table 3. Barriers to Online Lectures

\begin{tabular}{ccc}
\hline Types of Barriers & Frequency & Percentage \\
\hline Internet Connection/Signal & 57 & $76 \%$ \\
\hline Internet Quota & 17 & $22,67 \%$ \\
\hline Devices & 1 & $1,33 \%$ \\
\hline
\end{tabular}

Based on table 3, the results showed that the main obstacle for mathematics education students in online learning in the Covid-19 pandemic era was the poor internet connection. It occurred because the majority of students were located in areas with poor networks. Based on interviews with respondent 1 , he/she stated that they often joined online lectures in mountains and ports to gained a good internet connection. Also, the second obstacle faced by students was that online learning requires a lot of internet quota that leads students to need more financial for it. The last obstacle faced was minimal online lecture equipment.

Despite many obstacles, but online lecture turned out that this online lecture provided several conveniences for students. The convenience obtained by students during online lectures was presented in Table 4.

Table 4. The Convenience of Online Lectures

\begin{tabular}{ccc}
\hline Kind of Convenience & Frequency & Percentage \\
\hline A flexible place to study & 57 & $76 \%$ \\
\hline Unlimited study time & 18 & $24 \%$ \\
\hline
\end{tabular}

Based on table 4, it was found that there were two facilities obtained by mathematics education students during online lectures, namely a flexible learning place and unlimited study time. This was in line with Mustofa, Chodzirin, Sayekti, \& Fauzan (2019) that demonstrated that online learning was very good to use because it was not limited by space and time. Also, Setyadi (2017) states that using a web-based (online) mathematics learning platform could reduce static learning atmosphere, and able to create an attractive and effective learning atmosphere. In the context of learning mathematics, technology was very well used to visualize material such as geometric objects and made learning more meaningful (Herron, 2010).

Based on the obstacles and conveniences faced by mathematics education students during online lectures, students' assessments of the effectiveness of online lectures were obtained. The results of the assessment were presented in Table 5. 
EDUMATIKA: Jurnal Riset Pendidikan Matematika

Table 5. Assessment of the Effectiveness of Online Lectures

\begin{tabular}{ccc}
\hline Response & Frequency & Percentage \\
\hline Very Effective & 1 & $1,3 \%$ \\
\hline Effective & 9 & $12 \%$ \\
\hline Less Effective & 59 & $78,7 \%$ \\
\hline Ineffective & 2 & $2,7 \%$ \\
\hline Very Ineffective & 4 & $5,3 \%$ \\
\hline
\end{tabular}

Based on table 5, we found various respond from student assessments of the effectiveness of online lectures during the Covid-19 pandemic. There is 1 respondent (1.3\%) said that it very effective, 9 students (12\%) demonstrated effectively, and most of the students (about 59 (78.7\%)) said that it's less effective, while there were 2 student (2.7\%) and 4 students (5.3\%) said it is no effective and very ineffective, respectively. The data indicates that online lectures in the pandemic era had not been effective, because online learning/lectures were not carried out with careful preparation. This was due to online lectures were used as the impact of government policy on banned gathering to break the chain of covid-19. This condition did not only occur in Indonesia, especially the mathematics education program of IAIN Kendari but most countries with inadequate online learning tools. According to the suggestion of Basilaia \& Kvavadze (2020) in their study that investigated the country's ability to organize online learning during the Covid-19 pandemic the development of online-based lectures should be done continue to be carried out more effective of online lectures that liked and helpful to students.

Another fact was obtained from this study in student responses about the sustainability of the implementation of online lectures after the Covid-19 pandemic. The question posed was "If the Covid-19 pandemic ends, still you want to online learning continue?" Student response data were presented in Table 6.

Table 6. Students Responses about Online Lectures Post-Covid-19 Pandemic

\begin{tabular}{ccc}
\hline Respons & Frequency & Percentage \\
\hline Yes & 2 & $2,7 \%$ \\
\hline No & 45 & $60 \%$ \\
\hline Blanded Learning & 28 & $37,3 \%$ \\
\hline
\end{tabular}

Based on table 6 , we found that 46 students or about $60 \%$ expressed their unwillingness to continuing online lectures post-pandemic, and only 2 respondents or $2.7 \%$ said they agreed if online lectures continued. This was in line with the study was conducted by Anhusadar (2020) which states that $100 \%$ of PIAUD students didn't want to conduct online lectures continue for various reasons. Also, Syah (2020) states that online learning in the era of the Covid-19 pandemic had not run optimally due to the lack of teachers' ability to use information technology, their 
infrastructure, and limited networks. However, table 6 also obtained student responses to carried out combined face-to-face and online lectures, known as blended learning.

Blended learning was defined as a learning process that combines face-to-face and online learning (Garrison \& Vaughan, 2012). This learning model was interesting to implement because it could increase the enthusiasm of students in learning, and increase their interest in learning (Tuomainen, 2016). It was supported by several studies which state that learning/lectures with blended learning were very effective in improving understanding of mathematical concepts, learning achievement, communication skills, and so on (Lin, Tseng, \& Chiang, 2017; Setyaningrum, 2018; \& Riasari, 2018).

\section{CONCLUSIONS}

The responses of mathematics pre-service teachers about online lectures in the era of the Covid-19 pandemic found that the online platforms that were often used were WhatsApp, Google Classroom, YouTube, email, Facebook, Zoom and a combination of several media/platforms respectively, and WhatsApp becomes most liked online platform and Zoom was most disliked platform. In these lectures the obstacles faced by students were poor internet connection, requiring a lot of internet quota, and minimal online lecture devices, while the convenience obtained was being able to study anywhere (home, garden, beach, etc.) and had learning time unlimited. Concerning the effectiveness of online lectures, the responses obtained were very effective (1.3\%), effective (12\%), less effective (78.7\%), ineffective (2.7\%), and very ineffective (5.3\%). In general, mathematics education students (mathematics pre-service teachers) responded that when the Covid19 pandemic ended (60\%) students wanted to learn face-to-face, $(2.7 \%)$ wanted online, and (37.3\%) wanted blended learning. Thus, the Covid-19 pandemic could be the beginning of a change in the learning paradigm that was not only face-to-face but can be carried out online or combining the two things (blended learning).

\section{REFERENCES}

Anhusadar, L. O. (2020). Persepsi Mahasiswa PIAUD terhadap Kuliah Online di Masa Pandemi. KINDERGARTEN: Journal of Islamic Early Childhood Education, 3(1), 44-58. https://doi.org/dx.doi.org/10.24014/kjiece.v3i1.9609

Basilaia, G., \& Kvavadze, D. (2020). Transition to Online Education in Schools during a SARS-CoV-2 Coronavirus (COVID-19) Pandemic in Georgia. Pedagogical Research, 5(2), 1-9. https://doi.org/10.29333/pr/7937

BPS. (2019). Banyaknya Desa/Kelurahan Menurut Keberadaan Base Transceiver Station (BTS), Sinyal Telepon Seluler, Dan Sinyal Internet GSM Atau CDMA. https://sultra.bps.go.id/

Garrison, D. R., \& Vaughan, N. D. (2012). Blended Learning in Higher Education: Framework, Principles, and Guidelines. Blended Learning in Higher Education: Framework, Principles, and Guidelines. https://doi.org/10.1002/9781118269558

Herron, J. (2010). Implementation of Technology in an Elementary Mathematics Lesson: The Experiences of Pre-Service Teachers at One University. SRATE Journal, 19(1), 22-29. Retrieved from 
EDUMATIKA: Jurnal Riset Pendidikan Matematika

e-ISSN 2620-8911

Volume 3, Nomor 2, November 2020

p-ISSN 2620-8903

http://files.eric.ed.gov/fulltext/EJ948684.pdf

Jolanta, B., \& Majella, D. (2020). Covid-19 Practice in Primary Schools in Ireland Report. Maynooth. https://doi.org/10.13140/RG.2.2.14091.03369

Kurt, S. (2010). Technology use in elementary education in Turkey: A case study. New Horizons in Education, 58(1), 65-76.

Lin, Y. W., Tseng, C. L., \& Chiang, P. J. (2017). The effect of blended learning in mathematics course. Eurasia Journal of Mathematics, Science and Technology Education, 13(3), 741-770. https://doi.org/10.12973/eurasia.2017.00641a

Mulenga, E. M., \& Marbán, J. M. (2020). Is COVID-19 the Gateway for Digital Learning in Mathematics Education? Contemporary Educational Technology, 12(2), 1-11. https://doi.org/10.30935/cedtech/7949

Mustofa, M. I., Chodzirin, M., Sayekti, L., \& Fauzan, R. (2019). Formulasi Model Perkuliahan Daring Sebagai Upaya Menekan Disparitas Kualitas Perguruan Tinggi. Walisongo Journal of Information Technology, I(2), 151. https://doi.org/10.21580/wjit.2019.1.2.4067

Perienen, A. (2020). Frameworks for ICT Integration in Mathematics Education - A Teacher's Perspective. Eurasia Journal of Mathematics, Science and Technology Education, 16(6). https://doi.org/10.29333/ejmste/7803

Riasari, D. (2018). Peranan Model Pembelajaran Matematika Berbasis Blended Learning Terhadap Komunikasi Matematis Siswa dalam Materi Statistik Pada SMAN 1 Tapung. Jurnal Pendidikan Tambusai, 2(4), 813-820.

Setyadi, D. (2017). Pengembangan Media Pembelajaran Matematika Berbasis Web pada Materi Barisan dan Deret, $8(1), 1-7$.

Setyaningrum, W. (2018). Blended Learning: Does it help students in understanding mathematical concepts? Jurnal Riset Pendidikan Matematika, 5(2), 244-253. https://doi.org/10.21831/jrpm.v5i2.21428

Surat Edaran Menteri Pendidikan dan Kebudayaan Nomor 4 Tahun 2020 tentang Pelaksanaan Kebijakan Pendidikan dalam Masa Darurat Penyebaran Corona Virus Disease (Covid-19).

Surat Edaran Direktur Jenderal Pendidikan Islam Nomor 657/03/2020 tentang Upaya Pencegahan Penyebaran COVID 19 (Corona) di Lingkungan Perguruan Tinggi Keagamaan Islam.

Surat Edaran Rektor IAIN Kendari Nomor 0125/ln.23/03/2020 tentang Perkuliahan Online.

Syah, R. H. (2020). Dampak Covid-19 pada Pendidikan di Indonesia: Sekolah, Keterampilan, dan Proses Pembelajaran. SALAM: Jurnal Sosial Dan Budaya Syar-I, 7(5). https://doi.org/10.15408/sjsbs.v7i5.15314

Tuomainen, S. (2016). A Blended Learning Approach to Academic Writing and Presentation Skills. International Journal on Language, Literature and Culture in Education, 3(2). https://doi.org/10.1515/l1ce-2016-0009

Viajayani, E., Radiyono, Y., \& Rahardjo, D. (2013). Pengembangan Media Pembelajaran Fisika Menggunakan Macromedia Flash Pro 8 Pada Pokok Bahasan Suhu Dan Kalor. Jurnal Pendidikan Fisika Universitas Sebelas Maret, 1(1), 144-156. 